\title{
THE POTENTIAL NATURAL HAZARDS TO BE CONSIDERED IN THE DESIGN AND EXPLOITATION OF THE AERIAL ROPE-WAY IN THE “GORA SOBOLINAYA” MOUNTAIN-SKIING RESORT (SOUTHERN PRIBAIKALIA, RUSSIA)
}

\author{
Alena V. Kadetova, Elena A. Kozireva \\ Institute of the Earth's Crust Academy of Sciences Siberian Branch, Laboratory of engineering geology and \\ geoecology, Lermontov Street 128, 664033 Irkutsk, Russia, alena-kadetova@yandex.ru, \\ kozireva@crust.irk.ru
}

\begin{abstract}
The paper deals with investigation of potential geological hazards to be taken into consideration in designing of the aerial rope-way, as well as problems of development of the recreation infrastructure in mountain lands with the complicated building conditions.
\end{abstract}

Key words: exogenous geological processes.

\section{Introduction}

The paper deals with the study of exogenic geological processes that develop in the influence area of the "Gora Sobolinaya" mountain-skiing complex. The complex was founded in late 1970s within the watershed area of rivers Kharlahta and Babkha in the south-western shore of Lake Baikal. The region is marked by attractive conditions for the active winter holiday: a lot of sunny days within the year, abundance of snow and diversity of ski-tracks. The mountain-skiing resort is situated at the elevation of $1001 \mathrm{~m}$ a.s.l., the maximum slope is $48.8^{\circ}$, the total length of ski-tracks $>12 \mathrm{~km}$. The popularity of mountain-skiing and growing accomodation capacity of the resort complex require the expansion of its infrastructure: building of new structures, widening of ski-tracks etc.; all these factors will provide the large technogenic load on the geological environment of the territory.

The paper aims to study the general engineering-geological situation in the site of the aerial ropeway construction, and to investigate the hazardous exogenic processes to prevent the eventual accidents. The planned aerial rope-way system belongs to the $1^{\text {st }}$ class of amenability level according to the GOST 27751-88; it presents the linear feature with bearing poles resting on the solid reinforced concrete basement (buried $0.1 \mathrm{~m}$ deeper of the frozen rocks stratum), and two rope-driving stations: 1) the lower station serving as drive-tension mechanism (Station I), and 2) the return motion mechanism atop of the mountain (900-910 m a.s.1.) (Station II). This structure belongs to the objects of high social amenability. The natural condition of the region such as considerable seasonal variations of temperature, seasonal freezing and thawing of soil, undulating relief and high seismicity, produce definite troubles to construction and exploitation of the lifting systems. 

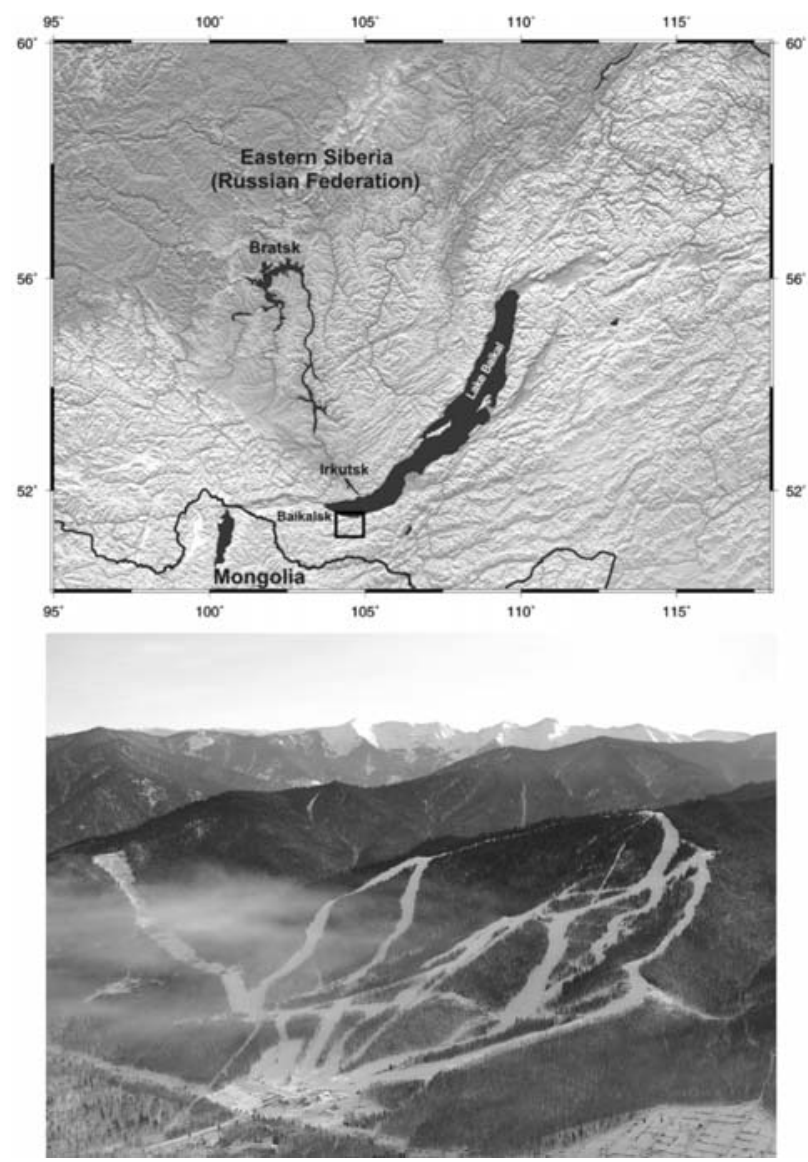

Fig. 1: (upper): location map. Squares symbolize the investigation area; (lower): general view of the "Gora Sobolinaya" mountain skiing comlex (Photo by Alexander Sizov).

\section{Geological and geographical setting}

\subsection{Geomorphology and relief}

The discussed area occupies the territory of the Baikal rift zone within the central part of Euro-Asian mainland. In the context of the specific geological structure, history of development, kinematics of tectonical movement in the upper area of lithosphere, the territory is marked by complicated engineering-geological conditions: the mountainous relief formed by recent tectonical movements. The engineering works of the "Gora Sobolinaya" complex are located in the piedmont area of KhamarDaban mountain ridge marked by the occurrence of paleo-peneplane elements, sharp crests, peaks, the elevation ranging from $500 \mathrm{~m}$ to $1001 \mathrm{~m}$ a.s.l. (Fig. 1). The piedmont territory composed of coarse clastics is gently dipped towards the lake; the width of piedmont plain ranges from $1 \mathrm{~km}$ to $2 \mathrm{~km}$.

The discussed territory is of the erosion-tectonical type, with dissected middle-height relief (Fig. 2). The elevation ranges from $700 \mathrm{~m}$ to $1758 \mathrm{~m}$ a.s.l., with the relative elevations of the valley floors 500-1000 m a.s.1 


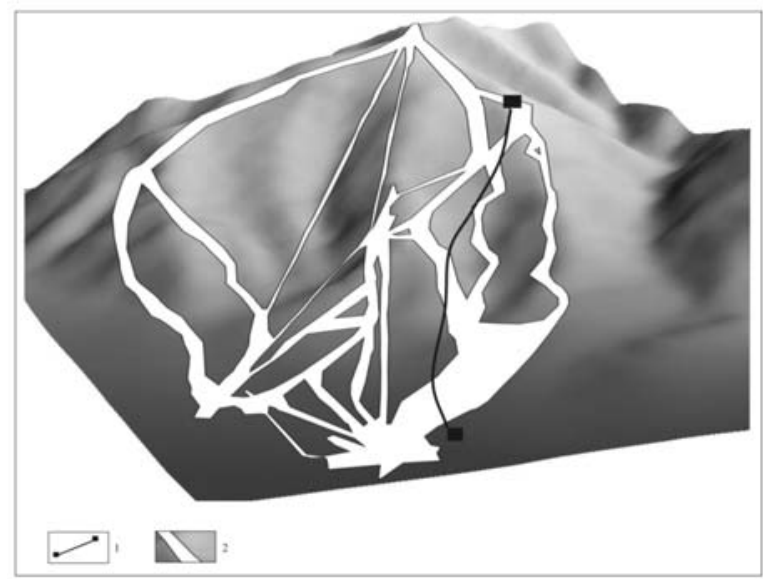

Fig. 2: The 3-D model of the Sobolinaya Mountain (1-the planned aerial rope-way; 2- skiing tracks).

\subsection{Climate}

The territory of Pribaikalia belongs to the region of continental climate: long and cold winter, short warm summer; the amplitude of temperature variations averages to $60^{\circ}$, the no-frosting periods lasting for 130 days.

The first autumn frosts occur in mid-September, the cases of late frosts are documented in May; the cases of zero crossing occur within the periods of 150-180 days. This is one of the most important factors of frost weathering of solid rocks. The continental climate is the cause of deep seasonal freezing and long-lasting periods of ground thawing. The atmospheric precipitation occurs primarily in the periods June-August; the monthly precipitation maximum being observed in July. Within the year, the precipitation amounts to $80-90 \%$ as rains, and $5-30 \%$ as solid precipitation. Thus, the most important climate factors are: frequent temperature drops, abundant atmospheric precipitation and deep seasonal ground freezing.

\subsection{Geological structure}

According to the Geological Map (1:200000) (1973), the main area of the discussed slope is presented by the Archeic-Lower Proterozoic formation of white marbles (in places by graphitic and phlogopite-containing ones), with lenticular intercalations of calciphyres, ophicalcites, pink diopsidic marbles, skarn and gneiss deposits (Fig. 3).

The foot area of the slope, and a definite part of its upper area are composed of non-segmented Early-Proterozoic rocks of compound structure, belonging to the Babkha massif. Here the basic rocks alternate with the enclosing rock mass. The petrographic composition of intrusions is presented by pyroxene-amphibole and olivine gabbro, gabbro-diabases, gabbro-diorites and diorites. Occasional dike formations are presented by diabases and diabasic porphyrites. The part of northern slope (the site of planned lifting system) is presented by Late-Proterozoic intrusions of the Sayan complex (third phase) composed of granitoide deposits and confined to slackened areas of deep faults. Granitoides are of pink, pinky-grey, reddish-pink and light-grey (almost white) color. 

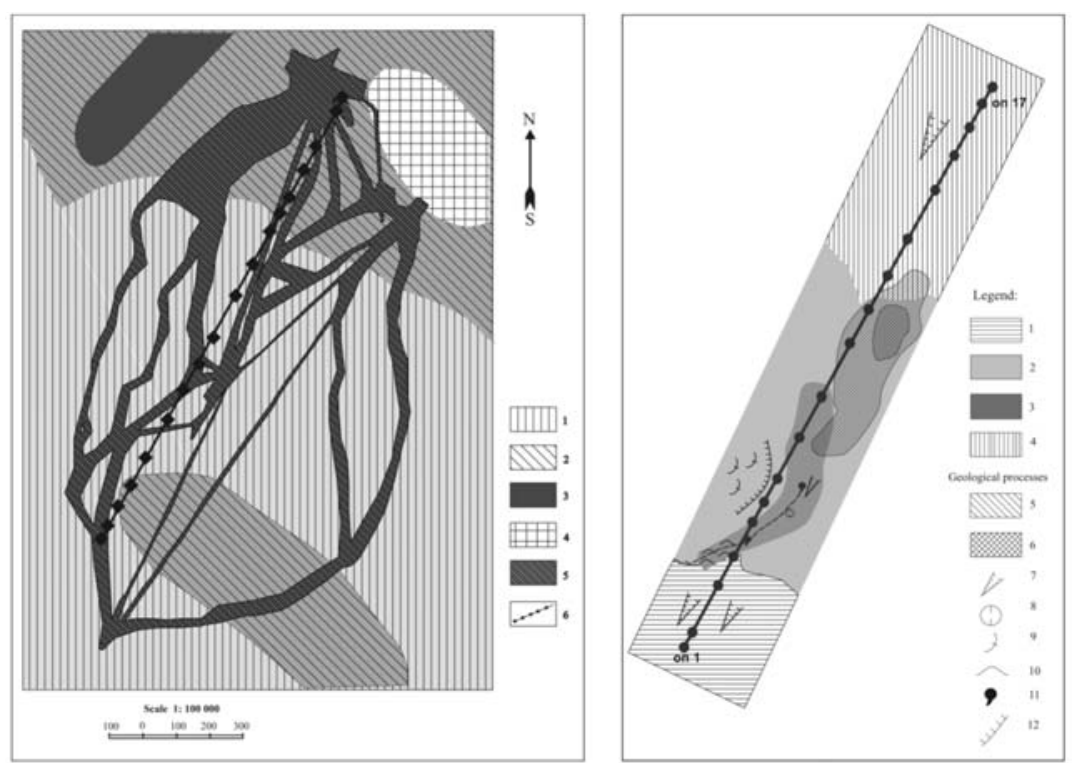

Fig. 3: (left):Geological index-map of the mountain-skiing complex`s territory: 1 -Archeir-Lower Proterozoic formation of white marbles with lenticular intercalations of calciphyres, ophicalcites, pink diopsidic marbles, skarn and gneisses; 2 - Late-Proterozoic intrusion of Sayan complex (3-rd phase) granitoides; 3 -river bed alluvial deposits of Holocene (cobble roundstone, gravel, semigravel); 4 - non-segmented intrusions of EarlyProterozoic rocks (gabbroides and diorites); 5 - skiing tracks; 6 - lifting system; (right): Index-map of engineering-geological zonation of lifting system route: 1 - slope of up to $15^{\circ}$ steepness; 2 - slope of up to $40^{\circ}$ steepness; 3 - creek valley; 4 - slope of $>40^{\circ}$ steepness; 5 - borders of overgrown old stone stream; 7 - erosion; 8 - suffosional subsidence; 9 - solifluction; 10 - swamping; 11 - groundwater discharge; 12 - cut slope.

\subsection{Geological processes}

The described territory belongs to the regions of high seismicity ( M9), as evidenced by the SeismoZoning Map-97. High seismicity in combination with typical geo-cryological conditions, specific hydro-meteorological and geologic-geomorphological conditions are the determining factors of exogenic geological processes such as weathering, mudstream, soil creep, rockfall, landslide etc.

Weathering. The processes of physical weathering intensely develop in mountainous areas marked by considerable temperature variations and frequent cases of zero crossing. Considerable disintegration of outcropped solid rocks is caused by thermal weathering. The amplitude of diurnal and annual temperature variations in the upper rock layer reach $40-50^{\circ}$ at the elevation mark $900 \mathrm{~m}$ a.s.l., and $70-80^{\circ}$ at $1700 \mathrm{~m}$ a.s.l. The variations of soil temperature at these elevations occur in the following manner: 320-350 cases of zero crossing within the year in the slopes of south-exposed slopes, and up to 200 cases in the north-exposed slopes. The repeating cases of heating and cooling produce the destructive effect upon physical characteristics of denudated rocks that turn into breakstone and gruss. Within the year, the influence of seasonal factors upon the rock weathering is observed. The winter time (December-March) is the period of the relative rest (Solonenko 1962). Along with the thermal weathering, the destruction and crushing of solid rocks occur due to frost wedging and chemical weathering as the consequence of dissolution of carbonates and other elements.

Gravitation processes. Wide occurrence of gravitation processes in the territory is attributed to a 
number of factors such as the rugged mountainous relief, extensive outcrop of solid rocks and their disintegration, high rate of physical weathering, abundant atmospheric precipitation, active tectonics and high seismicity. The phenomenon of rockfall is typical of the rocky slopes of valleys, dissected by narrow denudation rills of relatively small depth and length (Engineering geology of Pribaikalia 1968). In many cases, the rockfall masses contribute to formation of the mudstream solid phase. The rock debris of the size $0.2-0.4 \mathrm{~m}$ across are easily transported by water streams of $2-3 \mathrm{~m} / \mathrm{s}$ rate. The rock debris particles of size $>1.0 \mathrm{~m}$ across are typical only of the rockfall areas with intrusive formations. The detrital slopes (sometimes of large size) are present in the areas of outcropped solid rocks. The major amounts of loose rock debris accumulate in the detrital cone in late spring, summer and early autumn, i.e. during the periods of snow thawing, frequent cases of zero crossing and abundant atmospheric precipitation. This time is marked by the maximum stream of clastic material due to the water action, avalanche denudation, etc. The fluid soil creep is more typical of the northern offspur of Khamar-Daban mountain ridge. In the morphological aspects, the fluid soil creep from steep slopes occur in the form of stripping of the 3-5 m-wide (in places 10-12 $\mathrm{m}$-wide) and 0.2-0.3 m-thick bands of the earth mass. The triggering factors of the soil creep are generally the lateral erosion and cutting of slopes.

Permafrost processes. In the described territory the permafrost is of the sparse occurrence. In high mountain areas, the $80 \mathrm{~m}$-thick layers of frozen rocks occur in all elements of the relief (Leshchikov 1978). In the piedmont area with $\sim 1300 \mathrm{~m}$ a.s.l. elevation, the permafrost is of insular occurrence, typical of sodded and forested lowlands. The seasonal thawing of permafrost reaches $1.0-1.3 \mathrm{~m}$ depth in early summer and up to $2.0-2.5 \mathrm{~m}$ in late summer. The average of seasonal ground freezing depth reaches 1.8-2.3 m.

\section{Methods}

The investigation of natural hazards from exogenic geological processes, and the evaluation of engineering-geological potential of the geological environment are based on the following factors:

1. The preliminary works comprise:

- accumulation and analysis of the archive and published data concerning the area of planned works;

- interpretation of the space- and aerial photographs;

- analysis of engineering-geological data on the bore pits, stripping of overburden.

2. Field investigations:

- reconnaissance survey of slopes;

- geographical siting of skiing paths and location of the aerial rope-way bearing poles;

- the GPS survey of the rope-way profile;

- the route survey and description of the reference points (the sites for bearing poles) and the areas of developing geological processes.

3. The office works:

- the analysis of engineering-geological conditions of the building ground, using the archive and field materials;

- evaluation of natural and technogenic conditions in the building site;

- drawing of index maps of engineering-geological conditions in the aerial rope-way site;

- forecast of qualitative changes of the engineering-geological conditions in the region of planned work. 
During the preliminary works, the definite archive materials concerning the area of investigation were studied, including the scientific reports on the geological structure, seismotectonics and engineering-geological conditions of the territory. Interpretation of the space- and aerial photographs of different years, analysis of cartographic materials, as well as the materials from core drilling.

The reconnaissance survey was carried out to reveal the hazard of exogenic processes, degree of the rock weathering and rock strength properties in the context of construction of the bearing poles, the places of groundwater discharge, swamped areas and other natural phenomena.

The route survey for the aerial rope-way spreads over the existing mountain-skiing tracks with the rope-tow lifting systems up to the elevation marks of 899 m a.s.l., and the actually used lifting systems to check their serviceability. One of the survey routes runs in the evened part of the piedmont area to note the main water streams, as well as in the sites bearing poles foundation; the total amount of the survey points is 17 .

The geographical siting of observation points and the planned route of lifting system was based on the GPS methods. The total of noted and sited points amounted to 54: in the places of foundation of bearing poles located in the areas of groundwater discharge; in the areas of developing exogenic processes. For the analysis of cartographic materials and zonation of the course of the aerial ropeway, the geo-informational systems (GIS) were used. The GIS-systems are widely used in the engineering-geological practice for a number of purposes such as investigation and simulation of landslide hazard (Carrara and Pike 2008), estimation of the rockfall (Charalambous and Sakeliariou 2007), and mapping of erosional risks (Bathrellos and Skilodimou 2007). The maps of natural geodynamical conditions in the mountain-skiing complex, and the technogenic load, were prepared. The maps show the relief, the geological structure, the skiing-tracks and the lifting systems, the foundation of the rope-way poles, and record the exogenic geological processes. For the automation of the data analysis, the GIS methods were used. For solving of simple problems in the analysis of one or two layers, the thematic maps were drawn, which represent the general trends in the development of exogenic processes in different areas, and the natural conditions in the discussed territory. The thematic maps based on the methods of ranges and point density determines the scatter or concentration of the objects in different areas. This method can be used primarily for the group of layers, representing the exogenic processes, and particularly the relationships between the definite negative processes and the geological environment.

\section{Conclusions-Results}

The studied area is marked by the complicated climate, geological and seismic conditions. The planned lifting system (aerial rope-way) belongs to the category of high responsibility, and its exploitation will increase the load upon the geological environment. The comprehensive geo-ecological evaluation of the area was carried out to reduce the detrimental impacts of hazardous geological processes.

The area of the lifting system route is located on the north-exposed slope of north-western strike. The snow cover remains since early November till mid-May. The route will cross the following geomorphological elements: creek valley floors, slopes of two opposite watersheds, as well as the northexposed slope of the Sobolinaya Mountain (Fig2.). In the definite area of native slope, the spot cutting, surface grading (partially up to the horizontal level at 535-540 m level marks) were made. Uphill of these level marks, the slope was cut and stripped for laying of the mountain ski-runs. Due to the lack of sod and soil cover, the slope massif becomes subject to deep weathering that acceler- 
ates the rock destruction and increases the thickness of weathered zone. Besides, the technogenically disturbed slopes are subject to the intensive ground ablation, contributing to formation of new eluvial-deluvial deposits

The onslope deposits are presented by argillaceous rock debris of talus (Fig.1). The thickness of eluvial-deluvial deposits increases downhill. This distribution of the sedimentary cover depends on the intensity of ground ablation. The 100 m-long hillside cut for poling (poles N6 and N7) stripped the following soil column: the $0.2-0.3 \mathrm{~m}$-thick sod layer, the $20 \mathrm{~m}$-thick layer of heavily-eroded bedrocks and the non-uniform folded-fold massif of solid rocks such as granitoides, marbles, gneisses. The eroded rocks present the sandy loam-filled platy formations, easily crumbling to dust. In the lower part of soil column there are the seamy metamorphic rocks with high strength properties.

The poles N1, N2 and N3 are located in sites of $1-15^{\circ}$ inclination. The mountain slope is marked by the removed relief with small erosion forms and scours caused by the intensive ground ablation; the slope basement is composed of talus material (Fig.3).

The poles N4 and N5 are located on stable opposite slopes of creek valley; between them there is the swamped area with low-yield groundwater discharge. The geological map and material of field investigations show that the groundwater discharge is situated in the area of contact between the marbles of the Pereval-series and the intrusive gneisses. Besides, another low-yield groundwater discharge is located upslope, surrounded by the small-size swamp area. The melt and discharged waters fuse at the bottom of creek valley, forming the surface water stream "Stream" with well-defined channel of the U-shape profile, the $2.5 \mathrm{~m}$ width and up to $1.5 \mathrm{~m}$-high vertical edges. The valley bottom is covered by coarse pebble of local rocks (marble, granite).

Below the 545 m elevation mark, the "Stream" water stream was piped and conducted away from the territory of ski-depot. In autumn periods the water stream becomes poor in water, and freezes in winter. In May 2008, the inspection carried out in the resort territory with the snow cover still remaining in some places, did not find any sign of icing in the areas of the "Stream" water stream and groundwater discharge.

The hillside cutting and stripping were made for poles N6 and N7. In the places upslope, small solifluction deformations of $\sim 4 \mathrm{~m}$ length with $5 \mathrm{~m}$-high steps were found. The foundations of bearing poles were sited in stable slopes.

The pole N8 is located on the technogenically disturbed slope with graded surface, removed sod cover and stripped deluvial deposits and intensive ground ablation. The foundations for poles N9, $\mathrm{N} 10$ and N11 are located on the $40^{\circ}$ slope. The poles N10 and N11 are located within the area of stone river with outcropping coarse rock debris of relatively equal size ( 1.5-2.0 m across) in the centre of stone field, and grassed and bushy perimeter area (Fig.4). The stone field is stable, without any sign of movement (rock walls, fractures, zones of bleaching). The coarse rock debris insulate the bedrock surface from the solar radiation, saving the low temperature in the area of stone field and hindering the ground defrosting rate. High permeability of rock and the near-surface location of frozen rocks promote the intense downhill runoff of thawing water across the stone field body. Besides, the bushy surface of the stone field's lower edge is the evidence of its stability.

In the area of pole N12 (above the 700-710 m a.s.l. elevation marks) the slope steepness exceeds $40^{\circ}$, reaching in places $47^{\circ}$. The lack of sod cover is the cause of intensive downhill ground ablation that starts with the snow thawing; the intensity of ground ablation depends upon the thickness of snow cover and slope steepness. In the case of simultaneous snow thawing and excess raining, the rates of defrosting and intensity of ground ablation increase, entailing the erosion and dissection of the re- 

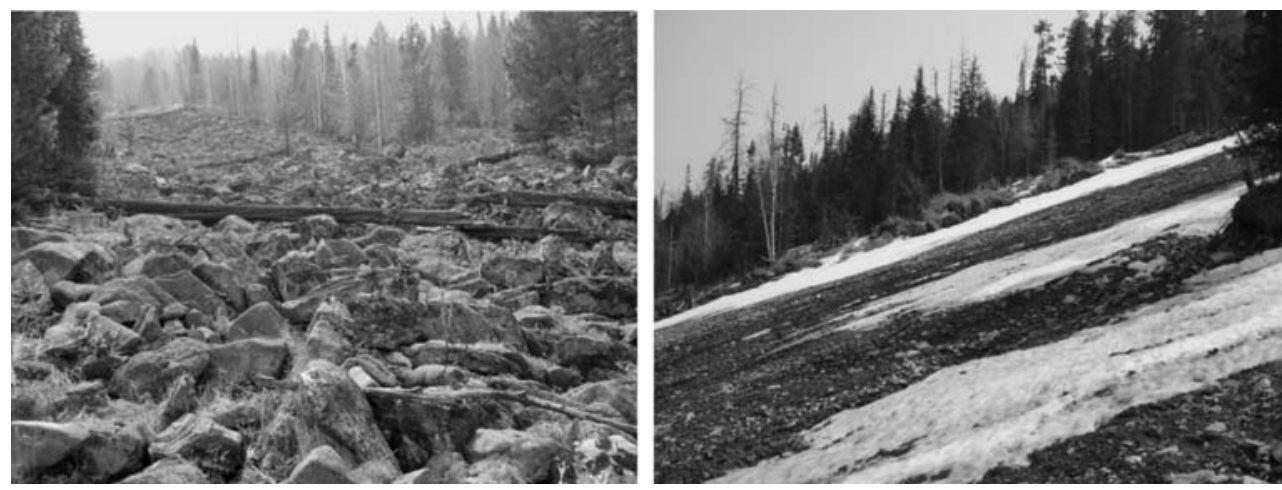

Fig. 4: Geological processes developing within the area of lifting system route: stone stream (left); ground ablation (right).

lief. Great amounts of fine- and medium-disperse material are transported downhill by ephemeral water streams. The intense ground ablation occurs also in the area of graded site of the Station II placed atop of the mountain at the elevation of 900-910 $\mathrm{m}$ a.s.1.

After the comprehensive investigation of the lifting system course, the engineering-geological zoning of the territory according to the slope steepness was made: 1$)$ zone of up to $15^{\circ}$ slope; 2) zone of $40^{\circ}$ slope; and 3) zone of $>40^{\circ}$ slope (Fig.3).

Each zone is marked by the occurrence of definite exogenic processes. The zone number 1 is marked by erosion development, here the poles NN 1-4 are sited; the zone number 2 (poles NN 5-11) is marked by seasonal (ephemeral) water streams, groundwater discharge, swamp areas, solifluction in the area of poles NN 5-7; the poles N 10 and N 11 are sited in the channel of the overgrown old stone stream; the zone number 3 is marked by the intense ground ablation; here the poles NN 12-17 are sited.

The study of geologic-geomorphological conditions, climate and other features of the territory, as well as the engineering-geological characteristics of the area of lifting system, revealed the occurrence of solid rocks covered by a thin layer of loose eluvial-deluvial deposits in the place of contact of poles with the geological environment. The course of the planned aerial rope-way will cross several geomorphological elements of similar genesis. The territory is marked by sloping surface and simple hydrogeological conditions scarcely affected by technogenic factors. According to these factors as well as to the Manual Building Code CП 11-105-97, the site for construction of the aerial rope-way can be referred to the category II of complexity of engineering-geological conditions.

The depth of foundation bury rules out the risks of deformation from the decrease of the soil's bearing power: in accordance with the engineering design, the foundation should be buried deeper of the seasonally frozen rock stratum. All foundations rest on either the solid rocks or the non-contracting eluvial-deluvial grounds.

In the area of the planned lifting system's foundation, no hazardous geological processes were found; this means that the poles rest on the stable ground, not subject to the influence of exogenic geological processes. The technogenic load within the discussed area is bound up with the construction of mountain-skiing tracks: the selective slope cutting, surface grading, removing of sod cover and snow retention on the slopes entail the increase of weathering rate, surface runoff and formation of the eluvial-deluvial layer. The interference in the geological environment is confined to the near-surface 
area and does not affect the mechanisms and components of the geosystem. All exogenic geological processes developing in the vicinity of the mountain-skiing tracks remain undisturbed, their dynamics obeying to natural climate factors.

In the context of the actual geologic-geomorphological conditions in the site and the invariable technogenic factors, no changes in the engineering-geological conditions and the safe exploitation of the aerial rope-way can be expected. Major part of its exploitation period is designed for winter months (since November till May); the maximum technogenic load will therefore fall on frozen slopes. It should be noted that the territory is marked by high degree of natural risk; in the course of exploitation of the aerial rope-way the yearly monitoring of the skiing-track and the bearing poles will be required to avoid the unreasonable load on the geological environment

\section{Acknowledgments}

The authors thank the management of the "Gora Sobolinaya" resort for their kind help in the investigations. The index-map for Fig.1 was drawn with the use of GMT program pack (Wessel et al. 2007). The work has been done with financial support of Russian Federation President's Grants Council.

\section{References}

Bathrellos G.D., Skilodimou H.D., 2007. Using the analytic hierarchy process to create an erosion risk map. A case study in Malakasiotiko stream, Trikala prefecture. Bulletin of the Geological Society of Greece, vol. XXXVII, 1904-1915.

Carrara A., Pike R. J., 2008. GIS technology and models for assessing landslide hazard and risk. Geomorphology 94, 257-260.

Charalambous S., Sakeliariou M., 2007. Estimation of rockfall hazard using a GIS-based three-dimensional; rockfall simulation model. Bulletin of the Geological Society of Greece, vol. XXXVII, 19341946.

Engineering geology of USSR. Vol. III. East-Siberia, 1977, Moscow, 643 pp. (in Russian).

General seismic zoning of the territory of Russian Federation. OCP-97. Complete set of maps and materials for the Guide of Building Rules - "Building in seismic regions", 1998, Moscow (in Russian).

Geological Map of USSR (1:200000). The East-Sayan series, sheet M-48-III.Explanatory note, 1973, Moscow. (in Russian)

Guide for Building Rules 11-02-96. Engineering survey for building purposes. (in Russian).

Guide for Building Rules 22-01-95. Geophysical factors of hazardous natural impacts. (in Russian).

Leshchikov F.N., 1978. Frozen rocks of Priangaria and Pribaikalia. Nauka, Novosibirsk, 139 pp. (in Russian).

Solonenko V.P., 1960. Essays of the engineering geology of East Siberia. Irkutsk, 86 pp. (in Russian).

Wessel P., W.H.F Smith, 2007. The Generic Mapping Tools. Technical Reference and Cookbook Version 4.2 . 